\title{
Daily Light Integral: A Research Review and High-resolution Maps of the United States
}

\author{
James E. Faust ${ }^{1}$ \\ Plant and Environmental Sciences Deptartment, Clemson University, E-143 Poole Agriculture Center, \\ Clemson, SC 29634 \\ Joanne Logan \\ Biosystems Engineering and Soil Sciences, University of Tennessee-Knoxville, 209 Biosystems \\ Engineering Soil Science Office, Knoxville, TN 37996
}

\begin{abstract}
The National Renewable Energy Laboratory developed the National Solar Radiation Database to provide accessible solar radiation data to the research community for various uses. Previously, we created a series of monthly daily light integral (DLI) maps to provide a tool for horticulturists to estimate the potential growth and flowering responses for various plants throughout the year. The original DLI maps were based on solar radiation data from 239 sites recorded from 1961 to 1990. The DLI maps presented in this article were created from an updated database that included data from 1998 to 2009. This database provides higher resolution data modeled from satellite images of cloud cover. The data are presented in pixels with each pixel representing $100 \mathrm{~km}^{2}$ of land across the lower 48 United States and Hawaii, whereas the Alaska data are $1600 \mathrm{~km}^{2}$ pixels. The database provided global horizontal irradiance data that were converted to DLI $\left(\mathrm{mol}^{\circ} \cdot \mathrm{m}^{-2} \cdot \mathrm{d}^{-1}\right)$ using the conversion factor of $0.007265 \mathrm{~mol}(400-700 \mathrm{~nm}) \cdot \mathrm{Wh}^{-1}(400-2700 \mathrm{~nm})$, which assumes that $45 \%$ of the solar radiation is in the photosynthetically active radiation $(P A R, 400-700 \mathrm{~nm})$ region and $4.48 \mu \mathrm{mol} \cdot J^{-1}$ is the conversion from radiometric to quantum units. The updated DLI maps provide more geographically precise data reflecting recent weather patterns. We present a comprehensive review of recent research exploring the growth and flowering responses of horticultural crops to DLI.
\end{abstract}

Daily light integral is a measure of the total photosynthetic photon flux $(P P F)$ density delivered over the course of 1 day. This measurement has proven to be an extremely useful tool for assessing the irradiance delivered to various horticultural crops, and thus has become widely adopted by professional horticulturists. A review of the recent academic research describing plant responses to DLI is presented in the Discussion section.

Published articles have used various terminologies to describe DLI, such as photosynthetic DLI, average daily $P P F$, daily irradiance, and daily $P A R$ integral. These terms are synonymous; therefore, we propose that the term DLI, by itself, adequately describes the daily accumulated photosynthetically available number of photons delivered to a given area over the course of 1 day. Predicating DLI with the terms mean or average may be appropriate for studies using solar radiation as the light source because the DLI value may vary widely during the experimental period. The concept of critical DLI was introduced in the 1980 s to describe the minimum DLI required for flower initiation, development, or both. Armitage et al. (1981) reported that seed geraniums required

Received for publication 16 Apr. 2018. Accepted for publication 14 June 2018 .

We thank the American Floral Endowment for their financial support of this project. Technical Contribution No. 6669 of the Clemson University Experiment Station. This material is based on work supported by NIFA/USDA, under project number SC-1700539.

${ }^{1}$ Corresponding author. E-mail: jfaust@clemson. edu.
$1.94 \mathrm{~mol} \cdot \mathrm{m}^{-2} \cdot \mathrm{d}^{-1}$ for flower initiation and $3.25 \mathrm{~mol} \cdot \mathrm{m}^{-2} \cdot \mathrm{d}^{-1}$ for flower development. More recently, Christiaens et al. (2014) used the term minimum DLI to describe the DLI required to maintain a steady state between photosynthesis and respiration, i.e., the light compensation point was expressed as a function of DLI rather than as the usual $P P F$. This value was estimated to be $1.7-2.1 \mathrm{~mol} \cdot \mathrm{m}^{-2} \cdot \mathrm{d}^{-1}$ for two azalea (Rhododendron simsii) cultivars, whereas the critical DLI for good quality post-production flowering quality was $3.3 \mathrm{~mol} \cdot \mathrm{m}^{-2} \cdot \mathrm{d}^{-1}$. Meanwhile, Garland et al. (2010) used the term minimum DLI to describe the lowest light level needed to produce high-quality plants, which they determined to be $10.0 \mathrm{~mol} \cdot \mathrm{m}^{-2} \cdot \mathrm{d}^{-1}$ for coleus (Solenostemon scutellarioides).

New terms have been introduced with the potential to enhance the value and meaning of DLI measurements. Gent (2014) presented hydroponic lettuce data using a normalized daily irradiance measurement, i.e., DLI expressed on leaf area rather than on ground area. This technique accounted for the effects of plant size on tissue concentrations of various plant metabolites. At any given DLI delivered based on ground area, smaller plants with a lower leaf area index will have a greater light intensity delivered per unit leaf area and concomitantly higher sugar contents. Therefore, higher DLIs (based on ground area) are required for larger plants to deliver an equivalent normalized DLI to smaller plants, i.e., the normalized DLI measurement compensates for changes in leaf area over time. Kjaer et al. (2012) introduced the term daily photosynthesis integral which also expresses DLI on a leaf area basis and thus is synonymous with normalized DLI. Kjaer et al. (2012) also introduced the term cumulative DLI which is equivalent to how the term degree-day represents the accumulated thermal time. This cumulative DLI concept has merit when a mean DLI provided over a long duration of time may not accurately represent the light environment due to seasonal fluctuations.

Irradiance response group is a term introduced to describe flowering responses to DLI (Erwin and Warner, 2002; Warner and Erwin, 2003). Two irradiance response groups were introduced: facultative irradiance and irradiance indifference. Facultative irradiance describes responses in which flower initiation occurs at an earlier developmental stage, i.e., lower node position, in response to a higher DLI. Plant species in this category demonstrate a reduced juvenile period under higher DLI. The irradiance indifference response occurs when a species exhibits no reduction in node number below the flower or inflorescence in response to DLI.

Daily light integral maps of the 48 contiguous states were first published in 2002 (Korczynski et al., 2002). At this time, DLI measurements were not widely used among professional horticulturists. However, the availability of affordable sensors, extension outreach (Torres and Lopez, 2010) and educational materials (Faust, 2012), and educational programs for professional horticulturists has resulted in rapid acceptance of the DLI concept and integration of this measurement into the horticultural jargon. The original DLI maps served as a valuable resource to educators in communicating the importance of DLI 
measurements in horticulture production systems. Today, growers frequently reference DLI measurements when conversing about environmental conditions and plant responses to those environments. This growth in knowledge has contributed to improved management of the light environment in the commercial production of a wide range of horticultural crops (Faust, 2012).

The DLI maps created in 2002 used spatial interpolation of solar radiation for 237 observation sites unequally distributed throughout the lower 48 states, or $\approx 34,000 \mathrm{~km}^{2}$ per site. Solar radiation was directly measured with radiation sensors and was likely very accurate because global horizontal incidence measurement accuracy is estimated at $5 \%$ when directly measured; however, many stations had missing data and several different models were used to fill in the gaps (Marion and Wilcox, 1994). Also, spatial interpolation using a limited number of sites added a higher degree of inaccuracy to these maps. Data for Hawaii and Alaska were not available at that time. Because the original maps were published, updated, highresolution data have been released from the National Renewable Energy Laboratory (Renewable Resource Data Center, 2018). Data for the contiguous 48 states and Hawaii are now available in $100 \mathrm{~km}^{2}$ resolution from 1998 to 2009, whereas Alaska data are available in $1600 \mathrm{~km}^{2}$ sections. These improvements in the available data justified recreating DLI maps for the United States. The objectives of this project were 1) to provide updated monthly DLI maps and 2) to review the research literature concerning plant growth and flowering responses of horticultural crops published since the original DLI maps were created.

\section{Materials and Methods}

The DLI maps presented in this article are based on the State University of New York/ Albany satellite radiation model that runs on a scale of $0.1^{\circ}$ in both latitude and longitude, or $\approx 10 \times 10 \mathrm{~km}$. This model was developed at the National Renewable Energy Laboratory and other universities for the U.S. Department of Energy (Perez et al., 2002). The model uses satellite imagery, daily snow cover data, and monthly averages of atmospheric water vapor, trace gases, and the amount of aerosols in the atmosphere to estimate hourly solar radiation. Ground measurement stations are used to validate the data. Nevertheless, there is uncertainty associated with the meteorological input to the model because some of the input parameters are not available at a $10-\mathrm{km}$ resolution. As a result, it is estimated that the modeled values are accurate to $\approx 15 \%$ of a true measured value within the grid cell (Wilcox, 2010).

For this study, the gridded $(10 \times 10 \mathrm{~km}$ or $\left.0.1 \times 0.1^{\circ}\right)$ monthly global horizontal irradiance data (1998-2009) for the lower 48 states and Hawaii were used. For Alaska, monthly average and annual average daily total solar radiation were averaged over surface cells of $\approx 40 \mathrm{~km}$ by $40 \mathrm{~km}$ in size. The Alaska spatial data were developed by the National Renewable Energy Laboratory (Renewable Resource Data Center, 2018) from the Climatological Solar Radiation Model.

Based on photon (quantum) theory, DLI was calculated from radiometric data by estimating $0.0072664 \mathrm{~mol}$ (400-700 nm). $\mathrm{Wh}^{-1}$ (400-2700 nm), which assumes that $45 \%$ of the solar spectrum is in the PAR (400$700 \mathrm{~nm}$ ) region and $4.48 \mu \mathrm{mol} \cdot \mathrm{J}^{-1}$ is the conversion from radiometric to quantum units (Blonquist and Bugbee, 2017). The lower 48 states and Hawaii data were merged with the Alaska data to create a single gridded dataset that were then used with ArcGIS (Esri, Redlands, CA) to create the monthly DLI maps (Fig. 1).

\section{Results}

The original DLI maps used a conversion factor that was $2.8 \%$ lower than the multiplier used on these updated maps. This conversion factor requires an estimate of solar energy in the PAR wavelengths $(400-700 \mathrm{~nm})$. The previous estimate was $42.9 \%$ based on Thimijan and Heins (1983), whereas the new estimate was $45 \%$ based on Blonquist and Bugbee (2017). In addition, the conversion from radiometric to quantum units was changed from 4.57 (Thimijan and Heins, 1983) to $4.484 \mu \mathrm{mol} . \mathrm{J}^{-1}$ (Blonquist and Bugbee, 2017). This change in conversion factor resulted in a slight upward shift in the DLIs shown across the country.

The maximum DLI range in the original maps was $55-60 \mathrm{~mol} \cdot \mathrm{m}^{-2} \cdot \mathrm{d}^{-1}$ which appears in the southwestern United States during May through July, whereas this range on the updated maps extends much further up the west coast throughout the summer months and into south central Washington during July. The updated maps have an additional DLI range $\left(60-65 \mathrm{~mol} \cdot \mathrm{m}^{-2} \cdot \mathrm{d}^{-1}\right)$ that appears in the southwest only during June. We suspect that these changes are real, i.e., they are a result of changes in the weather patterns rather than solely resulting from the change in the conversion factor, because the increase in DLI observed in the southwest and western United States is unique to those regions and is more prominent in the summer months. In comparison, the midwest and east coast of the United States exhibit only modest increases in DLIs along the edges of the contours.

The low end of the DLI range also added new values not seen in the original maps. The $0-5 \mathrm{~mol} \cdot \mathrm{m}^{-2} \cdot \mathrm{d}^{-1}$ zone was added because of the addition of Alaska on the updated maps. Parts of Alaska drop into the $0-5 \mathrm{~mol} \cdot \mathrm{m}^{-2} \cdot \mathrm{d}^{-1}$ range in October and continue through February, whereas the entire state is engulfed in this low DLI range throughout November, December, and January. The other addition to these maps is the state of Hawaii. The rapid changes in elevation and rainfall patterns over the relatively small landmass of the Hawaiian Islands result in pixel-to-pixel variation unlike that observed in the remainder of the country.
Although the DLI maps are useful for many facets of horticulture, perhaps the greatest application is for light management in controlled environments. In greenhouses, DLI delivered to the crop is reduced by the greenhouse infrastructure, glazing material, and shade curtains, whereas supplemental lighting can be used to increase DLI, especially during winter months. In warehouse production, vertical farming situations, and transoceanic shipping containers, sunlight is completely omitted from the production environment, so sole-source lighting systems supply the entire DLI delivered to the crop. The DLI maps provide the user with an estimate of ambient DLI conditions for specific locations and months of the year which allows the user to evaluate and modify the light environment to deliver equivalent DLI in the controlled environment. Several examples of the uses of the DLI maps in these controlled environments are discussed in the following paragraph.

In sole-source lighting situations, the DLI maps provide growers with benchmark targets for replacing solar radiation entirely with artificial light sources. The advent of lightemitting diodes (LEDs) into horticulture production systems in recent years has created the opportunity to provide upward of 40-50 $\mathrm{mol} \cdot \mathrm{m}^{-2} \cdot \mathrm{d}^{-1}$ in sole-source lighting situations. Dimmer switches on the newest generation of LEDs allow the grower to adjust the DLI as the crop mature and the leaf area increases.

Light transmission measurements are required for adapting the DLI maps to greenhouse production situations, i.e., for calculating the actual DLI transmitted through the greenhouse to the underlying crop. Light transmission varies with latitude and time of year because of the change in orientation of the earth and the sun. Transmission increases as the direction of the sunlight becomes more perpendicular to the greenhouse glazing material. The percentage of light transmission may range from $35 \%$ to $70 \%$ for a given location during the course of the year; thus, actual transmission measurements are required to accurately calculate DLI inside of greenhouses (Both and Faust, 2017). Light transmission through a greenhouse structure can be estimated by simultaneously making $P P F$ measurements with quantum sensors inside and outside the greenhouses. The DLI delivered to the crop can be estimated by multiplying the transmission percentage by the DLI indicated on the maps. For example, if the greenhouse light transmission is $50 \%$ in March in Pennsylvania which, according to the DLI maps, normally receives $25-30 \mathrm{~mol} \cdot \mathrm{m}^{-2} \cdot \mathrm{d}^{-1}$, then $12.5-15 \mathrm{~mol} \cdot \mathrm{m}^{-2} \cdot \mathrm{d}^{-1}$ would actually be delivered to the greenhouse crop.

The DLI maps can be used to determine the amount of supplemental lighting required to reach a minimum target DLI during low DLI months of the year. For example, in Seattle, WA during the month of January the outdoor DLI is $5-10 \mathrm{~mol} \cdot \mathrm{m}^{-2} \cdot \mathrm{d}^{-1}$. If the greenhouse transmission is $40 \%$ during the winter months, then the greenhouse crop will receive only $2-4 \mathrm{~mol} \cdot \mathrm{m}^{-2} \cdot \mathrm{d}^{-1}$. If $5 \mathrm{~mol} \cdot \mathrm{m}^{-2} \cdot \mathrm{d}^{-1}$ 

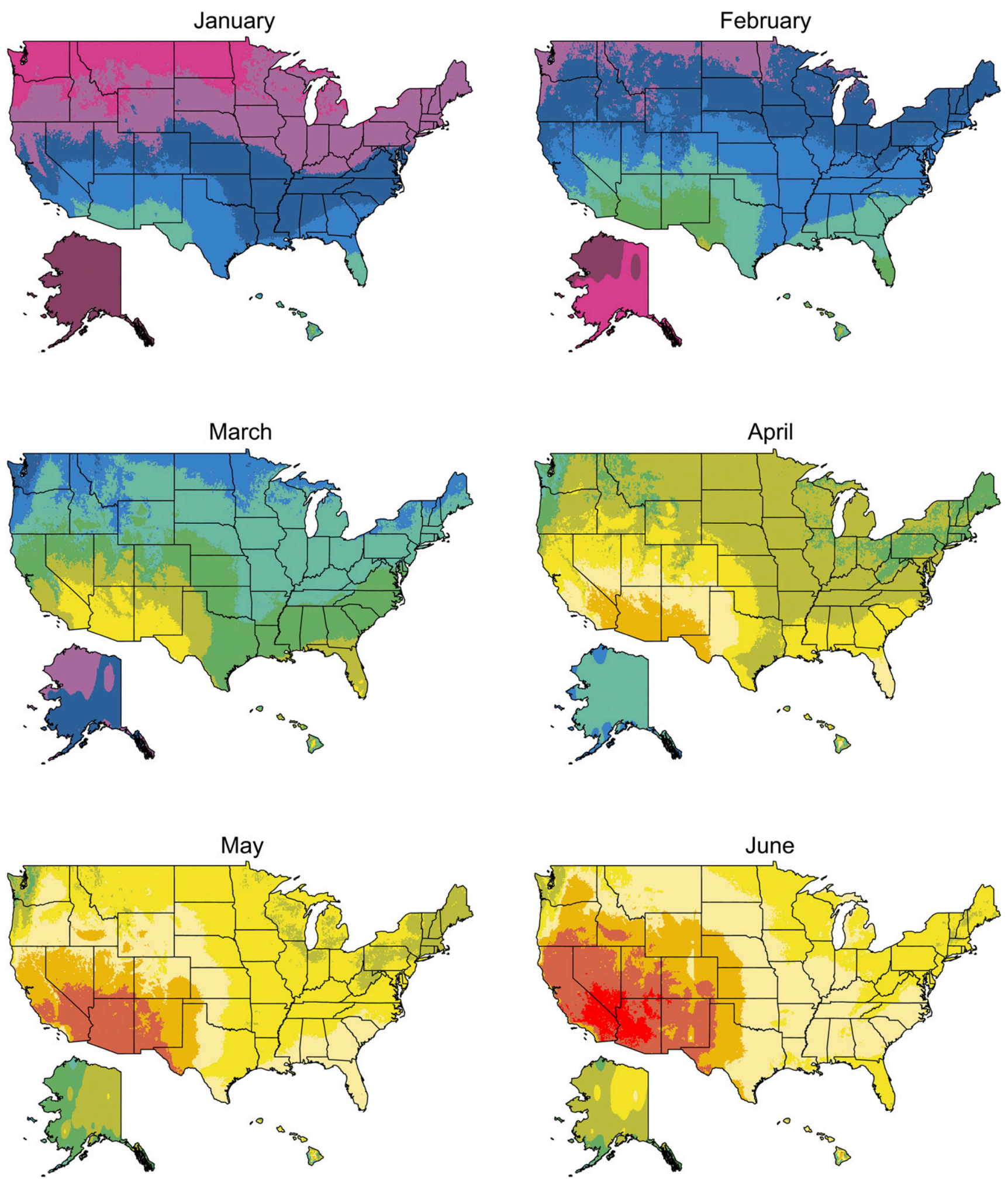

Fig. 1. Monthly daily light integral maps for the United States. Each pixel represents a $100 \mathrm{~km}^{2}$ of land for the lower 48 states and Hawaii, whereas Alaska data are based on $1600 \mathrm{~km}^{2}$ of land. Solar radiation data are from the National Solar Radiation Database (1998-2009) developed by the National Renewable Energy Laboratory (Renewable Resource Data Center, 2018). An interactive version of maps is available at https://webgis.coe.clemson.edu/storymaps/light-integral-map/.

is considered to be the lowest acceptable DLI for a greenhouse crop, then supplemental lighting must supply $1-3 \mathrm{~mol} \cdot \mathrm{m}^{-2} \cdot \mathrm{d}^{-1}$ to hit this target. If the greenhouse contains high-pressure sodium lamps that supply $50 \mu \mathrm{mol} \cdot \mathrm{m}^{-2} \cdot \mathrm{d}^{-1}$ to the underlying crop, then the lamps will need to operate $5.6-16.7 \mathrm{~h} \cdot \mathrm{d}^{-1}$ to reach the minimum acceptable DLI. One can also estimate that supplemental lighting will be needed from November through February to avoid the DLI delivered to the crop to be $<5 \mathrm{~mol} \cdot \mathrm{m}^{-2} \cdot \mathrm{d}^{-1}$.

The DLI maps can also be used to determine the need for shade curtains required to reach a maximum target DLI during high DLI months of the year. For example, our target is to supply a maximum DLI of $25 \mathrm{~mol} \cdot \mathrm{m}^{-2} \cdot \mathrm{d}^{-1}$ to a crop grown inside a greenhouse in St. Louis, MO, that has $60 \%$ light transmission during the summer months. We can calculate that additional shade will be needed during the months of May through August so as not to exceed the maximum DLI of $25 \mathrm{~mol} \cdot \mathrm{m}^{-2} \cdot \mathrm{d}^{-1}$. 

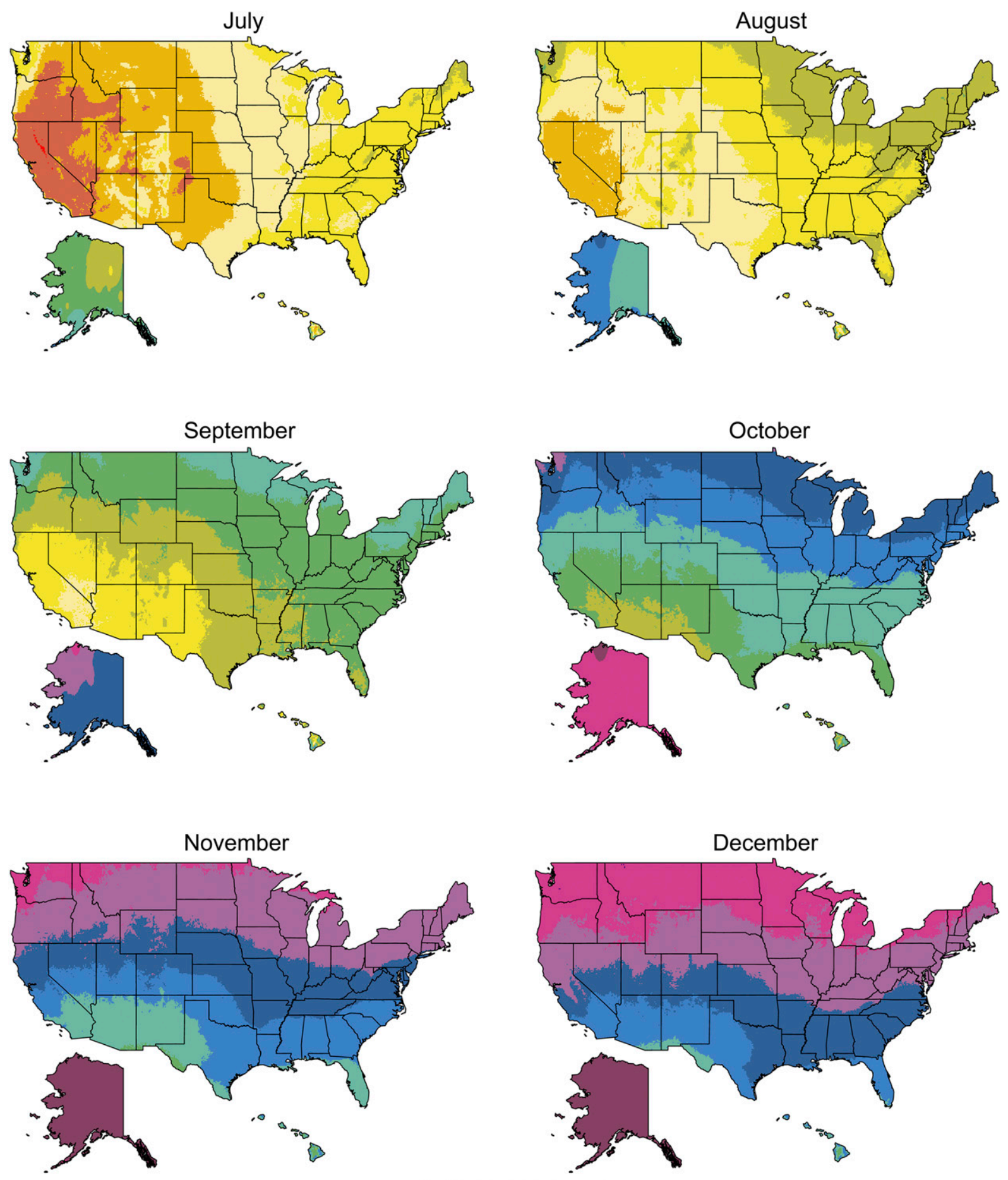

Daily Light Integral

$\left(\mathrm{mol} \mathrm{m}^{-2} \mathrm{~d}^{-1}\right)$
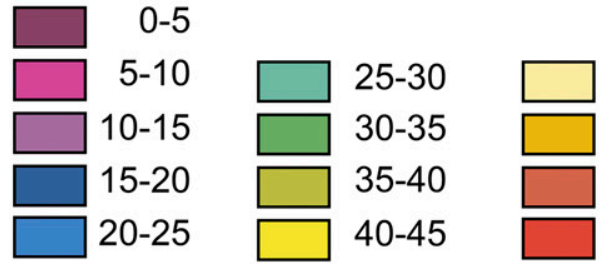

$45-50$

50-55

$55-60$

60-65

Fig. 1. (continued)

\section{Discussion}

Recent research exploring the influence of DLI on plant growth and development has focused on three main facets of horticulture which include herbaceous ornamentals production, lettuce grown in controlled environments, and turfgrass for golf courses. The unifying feature of these production situations is that they represent high-value crops in which light management techniques exist and have a significant impact on plant 
productivity, plant quality, the economics of production, or all.

At least 40 research articles exploring the plant responses to DLI have been published since the original DLI maps were published in 2002. Most of the research has focused on ornamental production in greenhouses; therefore, the review of the research in this area has been subdivided into five sections: stock plants, propagation, bedding plants, potted flowering plants, and herbaceous perennials. Following is a summary of the knowledge gained through recent research efforts.

Stock plants. Vegetatively propagated annuals begin their production cycle with the establishment of stock plants from which cuttings are harvested, packaged and shipped to wholesale growers for propagation. Chong (2006) focused on the effect of DLI on poinsettia (Euphorbia pulcherrima) cutting production and quality. The number of shoots developing within a stock plant canopy increased by $64 \%$ as DLI increased from 2.8 to $21.0 \mathrm{~mol} \cdot \mathrm{m}^{-2} \cdot \mathrm{d}^{-1}$. Subsequently, the cutting yield also increased linearly from 2.6 to 5.9 cuttings/plant/week over the same DLI range. Similarly, cutting quality increased with increasing DLI. For example, cutting dry mass and stem caliper increased as DLI increased up to $15 \mathrm{~mol} \cdot \mathrm{m}^{-2} \cdot \mathrm{d}^{-1}$. Chong et al. (2014) also showed that the leaf unfolding rate of the shoots in the poinsettia stock plant canopy increased up to $\approx 8 \mathrm{~mol} \cdot \mathrm{m}^{-2} \cdot \mathrm{d}^{-1}$. Stock plant canopies that have a higher density of shoots require a higher DLI to achieve the same leaf unfolding rate as stock plant canopies that have low shoot densities. For example, plants grown at a high density (129 shoots $\left./ \mathrm{m}^{2}\right)$ unfolded 0.25 leaves/d when grown at 10.6 $\mathrm{mol} \cdot \mathrm{m}^{-2} \cdot \mathrm{d}^{-1}$, whereas plants grown at a low density ( 43 shoots $/ \mathrm{m}^{2}$ ) achieved the same leaf unfolding rate at just $3.5 \mathrm{~mol} \cdot \mathrm{m}^{-2} \cdot \mathrm{d}^{-1}$.

The DLI delivered to the stock plant can affect adventitious root formation of the cuttings harvested from those stock plants. Lopez (2007) reported that stock plants grown at $12-15 \mathrm{~mol} \cdot \mathrm{m}^{-2} \cdot \mathrm{d}^{-1}$ improved rooting of black-eyed Susan vine (Thunbergia alata) cuttings, decreased rooting of jamesbrittenia (Jamesbrittenia grandiflora) and verbena (Verbena $\times$ hybrida) cuttings, and had no effect on the rooting of new guinea impatiens (Impatiens hawkeri) cuttings. Stock plant production of species such as Jamesbrittenia and Verbena creates a dilemma for cutting producers because higher DLI improves cutting production but may have detrimental effects on cutting performance in terms of root formation.

Propagation. Several studies have explored the effect of DLI in the propagation environment on adventitious root formation on unrooted cuttings, the quality the final rooted cuttings, and the subsequent growth and flowering of the rooted cutting after transplant. Enfield et al. (2003) reported that garden phlox (Phlox paniculata) cuttings required at least $3.5 \mathrm{~mol} \cdot \mathrm{m}^{-2} \cdot \mathrm{d}^{-1}$ for rapid, uniform rooting. Owen and Lopez (2018) propagated fountain grass (Pennisetum $\times$ advena) culm cuttings at DLIs from 4 to $16 \mathrm{~mol} \cdot \mathrm{m}^{-2} \cdot \mathrm{d}^{-1}$ and reported that the most efficient rooting occurred at $8-10 \mathrm{~mol} \cdot \mathrm{m}^{-2} \cdot \mathrm{d}^{-1}$, whereas the highest DLI $\left(16 \mathrm{~mol} \cdot \mathrm{m}^{-2} \cdot \mathrm{d}^{-1}\right)$ had lower culm and root density.

Currey et al. (2012) examined the effect of DLI after callus formation on the cuttings of nine annual species. The cuttings were propagated for $7 \mathrm{~d}$ at $\approx 5 \mathrm{~mol} \cdot \mathrm{m}^{-2} \cdot \mathrm{d}^{-1}$, then transferred to DLI treatments ranging from 1.2 to $12.3 \mathrm{~mol} \cdot \mathrm{m}^{-2} \cdot \mathrm{d}^{-1}$. The total dry mass and root:shoot ratio of marguerite daisy (Argyranthemum frutescens), twinspur (Diascia barbarae), nemesia (Nemesia fruticans), cape daisy (Osteospermum ecklonis), fan flower (Scaevola $\times$ hybrida), and verbena increased linearly as DLI increased from 1.2 to $12.3 \mathrm{~mol} \cdot \mathrm{m}^{-2} \cdot \mathrm{d}^{-1}$, whereas summer snapdragon (Angelonia angustifolia), lantana (Lantana camara), and bacopa (Sutera cordata) responded in a curvilinear pattern, i.e., the total shoot dry mass and root:shoot ratio increased up to $\approx 8 \mathrm{~mol} \cdot \mathrm{m}^{-2} \cdot \mathrm{d}^{-1}$ before plateauing at higher DLIs.

Lopez and Runkle (2008) propagated petunia (Petunia $\times$ hybrida) and new guinea impatiens at DLIs from 1.2 to $10.7 \mathrm{~mol} \cdot \mathrm{m}^{-2} \cdot \mathrm{d}^{-1}$, and Hutchinson et al. (2012) provided $1.2-12.3 \mathrm{~mol} \cdot \mathrm{m}^{-2} \cdot \mathrm{d}^{-1}$ during root development in propagation of four annual species. In both studies, the rooted cuttings were then transplanted and residual effects were recorded on subsequent growth and flowering. The root:shoot ratio of petunia and new guinea impatiens increased linearly over $16 \mathrm{~d}$ in propagation as DLI increased from 1.2 to $10.7 \mathrm{~mol} \cdot \mathrm{m}^{-2} \cdot \mathrm{d}^{-1}$, whereas the specific leaf area (leaf area/leaf dry mass) decreased, indicating plants with an extensive root system and less succulent leaves. Both of these characteristics are beneficial during postharvest shipping that may damage soft tissues and dislodge poorly developed root systems. These physical characteristics also help the newly transplanted liner transition to a brighter and drier production environment. Currey and Lopez (2015) observed increases in maximum gross photosynthesis on new guinea impatiens, geranium (Pelargonium $\times$ hortorum), and petunia cuttings during the rooting phase of propagation that resulted in an increase in biomass accumulation from 2 to $13 \mathrm{~mol} \cdot \mathrm{m}^{-2} \cdot \mathrm{d}^{-1}$. Subsequent responses to DLI persisted after transplant. For example, time to flower for petunia, new guinea impatiens, summer snapdragon, nemesia, cape daisy, and verbena decreased as the propagation DLI increased. Cape daisy was the only species that displayed an increased flower number as a result of the increasing DLI treatments in propagation. The consensus of these studies suggests a recommended DLI of $8-10 \mathrm{~mol} \cdot \mathrm{m}^{-2} \cdot \mathrm{d}^{-1}$ during the root development phase, and supplemental lighting should be provided to attain this target, if necessary.

Torres and Lopez (2011) propagated yellow trumpetbush (Tacoma stans) under DLIs ranging from 0.75 to $25.2 \mathrm{~mol} \cdot \mathrm{m}^{-2} \cdot \mathrm{d}^{-1}$. All growth measurements, such as shoot and root dry mass, leaf number, leaf area, and stem diameter, increased with increasing DLI. However, the authors recommend 14-16 $\mathrm{mol} \cdot \mathrm{m}^{-2} \cdot \mathrm{d}^{-1}$ for commercially accepted seedlings because of the rapid increase in plant height and internode length and reduction in chlorophyll content at DLIs $>16 \mathrm{~mol} \cdot \mathrm{m}^{-2} \cdot \mathrm{d}^{-1}$.

Bedding plants. Five bedding plant species [plumed cockscomb (Celosia argentea var. plumosa), bedding impatiens (Impatiens walleriana), scarlet sage (Salvia splendens), french marigold (Tagetes patula), and viola (Viola sp.)]were grown as seedlings at DLIs ranging from 4.1 to $14.2 \mathrm{~mol} \cdot \mathrm{m}^{-2} \cdot \mathrm{d}^{-1}$ (Pramuk and Runkle, 2005a). Shoot dry weight of four of the five species increased linearly as DLI increased throughout the entire range, whereas scarlet sage dry weight only increased up to $12 \mathrm{~mol} \cdot \mathrm{m}^{-2} \cdot \mathrm{d}^{-1}$. Then, seedlings were transplanted and grown at 8.5 $\mathrm{mol} \cdot \mathrm{m}^{-2} \cdot \mathrm{d}^{-1}$ until they flowered. The DLI provided during the propagation environment affected the subsequent growth and flowering after transplant. Time to flower decreased as DLI increased; however, plant quality was reduced because of early flowering, as this resulted in plants with less dry weight and fewer flower buds at the time of first open flower.

Although greenhouse experiments are typically limited to DLIs up to $25 \mathrm{~mol} \cdot \mathrm{m}^{-2} \cdot \mathrm{d}^{-1}$, Faust et al. (2005) grew eight species of bedding plants outdoors to achieve DLIs up to $43 \mathrm{~mol} \cdot \mathrm{m}^{-2} \cdot \mathrm{d}^{-1}$. Ageratum (Ageratum houstonianum), petunia, African marigold (Tagetes erecta), scarlet sage, vinca (Catharanthus roseus), and zinnia (Zinnia elegans) increased in biomass as DLI increased up to $43 \mathrm{~mol} \cdot \mathrm{m}^{-2} \cdot \mathrm{d}^{-1}$, whereas shade-tolerant species such as wax begonia (Begonia $\times$ semperflorenscultorum) and bedding plant impatiens reached their maximum biomass accumulation at $\approx 19 \mathrm{~mol} \cdot \mathrm{m}^{-2} \cdot \mathrm{d}^{-1}$.

Nemali and van Iersel (2004a) showed that wax begonias physiologically adapt to low DLI $\left(5.3 \mathrm{~mol} \cdot \mathrm{m}^{-2} \cdot \mathrm{d}^{-1}\right)$ by increasing the leaf chlorophyll concentration, and they adapt to high DLI $\left(19.4 \mathrm{~mol} \cdot \mathrm{m}^{-2} \cdot \mathrm{d}^{-1}\right)$ by increasing the maximum gross photosynthesis. Garland et al. (2010) reported that variegation (nongreen areas) of coleus increase as DLI increases up to $10 \mathrm{~mol} \cdot \mathrm{m}^{-2} \cdot \mathrm{d}^{-1}$.

Flowering responses can be quantified by recording the time to flower (or the reciprocal of the number of days to flower which is described as the rate of progress to flower), flower number, or flower size. In general, time to flower decreases at a decreasing rate as DLI increases until an asymptote is reached - the DLI above which no additional reduction in time to flower has been described in several studies. This maximum DLI has been reported as $10.5 \mathrm{~mol} \cdot \mathrm{m}^{-2} \cdot \mathrm{d}^{-1}$ for impatiens (Warner and Erwin, 2005); $15 \mathrm{~mol} \cdot \mathrm{m}^{-2} \cdot \mathrm{d}^{-1}$ for plumed cockscomb $(C$. argentea) (Pramuk and Runkle, 2005b); $17.5 \mathrm{~mol} \cdot \mathrm{m}^{-2} \cdot \mathrm{d}^{-1}$ for pot marigold (Calendula officinalis), mimulus (Mimulus $\times$ hybridus), and wishbone flower (Torenia fournieri) (Warner and Erwin, 2005); $19 \mathrm{~mol} \cdot \mathrm{m}^{-2} \cdot \mathrm{d}^{-1}$ for ageratum, marigold, vinca, and petunia (Blanchard et al., 2011a; Faust et al., 2005); $21.8 \mathrm{~mol} \cdot \mathrm{m}^{-2} \cdot \mathrm{d}^{-1}$ for snapdragon (Antirrhinum majus) (Warner and Erwin, 2005); 
$25 \mathrm{~mol} \cdot \mathrm{m}^{-2} \cdot \mathrm{d}^{-1}$ for scarlet sage and french marigold (Moccaldi and Runkle, 2007); and $43 \mathrm{~mol} \cdot \mathrm{m}^{-2} \cdot \mathrm{d}^{-1}$ for zinnia (Faust et al., 2005). The maximum flower number for petunia occurred at $19 \mathrm{~mol} \cdot \mathrm{m}^{-2} \cdot \mathrm{d}^{-1}$ (Blanchard et al., 2011b), $21.8 \mathrm{~mol} \cdot \mathrm{m}^{-2} \cdot \mathrm{d}^{-1}$ for bedding plant impatiens, mimulus, snapdragon, and torenia (Warner and Erwin, 2005); 25 $\mathrm{mol} \cdot \mathrm{m}^{-2} \cdot \mathrm{d}^{-1}$ for marigold (Moccaldi and Runkle, 2007); and $26 \mathrm{~mol} \cdot \mathrm{m}^{-2} \cdot \mathrm{d}^{-1}$ for celosia (Pramuk and Runkle, 2005b). The highest flower counts reported for petunia, vinca, and zinnia occurred at $43 \mathrm{~mol} \cdot \mathrm{m}^{-2} \cdot \mathrm{d}^{-1}$ (Faust et al., 2005). This observation actually reflects the effect of DLI on lateral branching because each new lateral shoot results in additional flowers. In many DLI studies, the optimal time to flower or highest flower number occurred at the maximum DLI treatment provided during the experiment; thus, the uppermost target DLI for flowering is not known. However, it is reasonable to expect that shade-tolerant bedding plants flower well at 5$10 \mathrm{~mol} \cdot \mathrm{m}^{-2} \cdot \mathrm{d}^{-1}$, whereas most "full sun" bedding plant species are of high commercial quality when grown at DLIs ranging from 15 to $25 \mathrm{~mol} \cdot \mathrm{m}^{-2} \cdot \mathrm{d}^{-1}$. Generalizations regarding DLI on flower size can be difficult because of the differing morphological characteristics of various species. However, average daily temperature is most often considered to be the primary factor that affects the size of flower petals and bracts, whereas DLI has a greater impact on the number of flowers formed within a single inflorescence; therefore, species in the Asteraceae family, such as marigold and zinnia, are more likely to produce larger inflorescences at higher DLIs because of the increase in the number of individual flowers within the composite inflorescence (Faust et al., 2005).

The effect of DLI on plant height cannot be generalized. Stem elongation is a complex phenomenon that is affected by day and night temperatures, plant spacing, and water stress. In species, such as petunia, increasing DLI resulted in progressively shorter plants; however, marigold, scarlet sage, and zinnia increased in plant height as DLI increased from 5 to $19 \mathrm{~mol} \cdot \mathrm{m}^{-2} \cdot \mathrm{d}^{-1}$ (Faust et al., 2005). Final plant height is also indirectly affected by DLI when high DLI stimulates flower initiation resulting in a lower node number below the first flower (Currey and Erwin, 2011).

Potted flowering plants. Currey and Erwin (2011) examined the effect of DLI on the growth and flowering of six kalanchoe species. Total flower number increased as DLI increased up to $17.2 \mathrm{~mol} \cdot \mathrm{m}^{-2} \cdot \mathrm{d}^{-1}$ for three species (Kalanchoe glaucescens, Kalanchoe manginii, and Kalancho rotundifolia), and as DLI increased up to $8.6 \mathrm{~mol} \cdot \mathrm{m}^{-2} \cdot \mathrm{d}^{-1}$ for the three other species (Kalanchoe laciniata, Kalanchoe nyikae, and Kalanchoe velutina). Warner and Erwin (2003) examined the flowering responses of several hibiscus species to DLI. The following DLIs were recommended to minimize time to flower for each species: Hibiscus cisplantus $\geq 25 \mathrm{~mol} \cdot \mathrm{m}^{-2} \cdot \mathrm{d}^{-1}$, Hibiscus moscheutos $>14 \mathrm{~mol} \cdot \mathrm{m}^{-2} \cdot \mathrm{d}^{-1}$, Hibiscus radiatus $>10 \mathrm{~mol} \cdot \mathrm{m}^{-2} \cdot \mathrm{d}^{-1}$, and Hibiscus trionum $>15 \mathrm{~mol} \cdot \mathrm{m}^{-2} \cdot \mathrm{d}^{-1}$.

Karlsson (2002) recommended a DLI of $10-11 \mathrm{~mol} \cdot \mathrm{m}^{-2} \cdot \mathrm{d}^{-1}$ for primrose (Primula vulgaris) because of little observed change in flower development on plants grown from 10 to $18 \mathrm{~mol} \cdot \mathrm{m}^{-2} \cdot \mathrm{d}^{-1}$. Large improvement in flower development occurred as DLI increased from 2 to $10 \mathrm{~mol} \cdot \mathrm{m}^{-2} \cdot \mathrm{d}^{-1}$. Although leaf unfolding rate is usually reported solely as a function of temperature, the leaf unfolding rate of primrose increased as DLI increased from 2 to $10 \mathrm{~mol} \cdot \mathrm{m}^{-2} \cdot \mathrm{d}^{-1}$.

Cyclamen (Cyclamen persicum) flowering was accelerated by increasing photoperiod and DLI, e.g., days to flower decreased in a 16-h photoperiod, delivering $9.8 \mathrm{~mol} \cdot \mathrm{m}^{-2} \cdot \mathrm{d}^{-1}$ in comparison with an 8-h photoperiod delivering $4.9 \mathrm{~mol} \cdot \mathrm{m}^{-2} \cdot \mathrm{d}^{-1}$ (Oh et al., 2008). Specific responses to photoperiod and DLI could not be differentiated in this study; however, a second study showed a rapid decrease in time to flower as DLI increased from 1.4 to $5.8 \mathrm{~mol} \cdot \mathrm{m}^{-2} \cdot \mathrm{d}^{-1}$ and then a small continual decline in time to flower at DLIs from 5.8 to $17.3 \mathrm{~mol} \cdot \mathrm{m}^{-2} \cdot \mathrm{d}^{-1}$ (Oh et al., 2009). Leaf number, flower number, and plant dry weight of cyclamen increased as DLI increased from 1.4 to $11.5 \mathrm{~mol} \cdot \mathrm{m}^{-2} \cdot \mathrm{d}^{-1}$. The authors conclude that supplemental lighting is beneficial for cyclamen when ambient DLI is $<12 \mathrm{~mol} \cdot \mathrm{m}^{-2} \cdot \mathrm{d}^{-1}$.

A high DLI $\left(17 \mathrm{~mol} \cdot \mathrm{m}^{-2} \cdot \mathrm{d}^{-1}\right)$ delivered to carpathian bellflower (Campanula carpatica) after visible flower bud resulted in an increase in flower size and flower number compared with plants grown at a low DLI $\left(5.7 \mathrm{~mol} \cdot \mathrm{m}^{-2} \cdot \mathrm{d}^{-1}\right)$ (Niu et al., 2001a). By contrast, the DLI delivered before visible bud had no effect on flowering. In an experiment providing a narrow range of DLIs, 6.3-8.5 $\mathrm{mol} \cdot \mathrm{m}^{-2} \cdot \mathrm{d}^{-1}$, dalmatian bellflower (Campanula portenschlagiana) and earleaf bellflower (Campanula cochlearifolia) increased in dry matter accumulation with increasing DLI (Kjaer et al., 2012). The specific leaf area also increased because of an increase in leaf dry mass and no change in leaf area. Leaf chlorophyll content decreased with increasing DLI apparently due to thicker leaves. Similar observations were reported on chrysanthemum (Chrysanthemum morifolium) (Kjaer and Ottosen, 2011).

Regal geraniums (Pelargonium $\times$ domesticum) exhibited genotypic variation in the timing of floral initiation when comparing DLI accumulated with chronological time (Loehrlein and Craig, 2004). The authors divided the flowering responses of regal geraniums into three categories: 1) DLI responsive, i.e., increasing DLI decreases time to flower, 2) time-responsive (which are also affected by DLI), and 3) nonresponsive to DLI, time, or both, i.e., require vernalization temperatures $<15.5^{\circ} \mathrm{C}$. Rohwer and Heins (2007) studied the effect of DLI before and during vernalization on the flowering of easter cactus (Hatiora gaertneri $)$. High DLI $\left(\approx 10 \mathrm{~mol} \cdot \mathrm{m}^{-2} \cdot \mathrm{d}^{-1}\right)$ during vernalization inhibited flowering possibly because of high temperatures; however, high DLI before vernalization, in contrast to low DLI $\left(\approx 4 \mathrm{~mol} \cdot \mathrm{m}^{-2} \cdot \mathrm{d}^{-1}\right)$, improved flowering.

Herbaceous perennials. In a study on yarrow (Achillea millefolium), gaura (Gaura lindheimeri), and lavender (Lavendula angustifolia), DLI treatments ranging from 5 to $20 \mathrm{~mol} \cdot \mathrm{m}^{-2} \cdot \mathrm{d}^{-1}$ had little effect on timing of flowering. The authors suggest $<5 \mathrm{~mol} \cdot \mathrm{m}^{-2} \cdot \mathrm{d}^{-1}$ as the minimum DLI for flowering; however, several qualitative characteristics improved and quantitative characteristics increased up to $20 \mathrm{~mol} \cdot \mathrm{m}^{-2} \cdot \mathrm{d}^{-1}$ (Fausey et al., 2005). For example, shoot dry mass, lateral branching, stem number, flowers per inflorescence of gaura, flower pigmentation of yarrow, and foliage pigmentation of lavender improved with higher DLI. Lower DLIs produced plants with weak stems that displayed prostrate growth rather than the desired upright growth. Thus, $15-20 \mathrm{~mol} \cdot \mathrm{m}^{-2} \cdot \mathrm{d}^{-1}$ proved to be the minimum DLI for high-quality plants of these species.

The shade-adapted perennial, American alumroot (Heuchera americana), was grown at DLIs from 7.5 to $21.8 \mathrm{~mol} \cdot \mathrm{m}^{-2} \cdot \mathrm{d}^{-1}$ (Garland et al., 2012). Shoot dry weight increased only up to $10.8 \mathrm{~mol} \cdot \mathrm{m}^{-2} \cdot \mathrm{d}^{-1}$, whereas leaf area and leaf number decreased as DLI increased above $14.9 \mathrm{~mol} \cdot \mathrm{m}^{-2} \cdot \mathrm{d}^{-1}$. Water use efficiency decreased by $17 \%$ as DLI increased from 7.5 to $21.8 \mathrm{~mol} \cdot \mathrm{m}^{-2} \cdot \mathrm{d}^{-1}$. Petiole length increased as DLI increased, whereas chlorophyll content decreased, which resulted in a poorer visual appearance for this ornamental species at the higher DLI treatments. For alumroot, the authors recommend a DLI between 11 and $15 \mathrm{~mol} \cdot \mathrm{m}^{-2} \cdot \mathrm{d}^{-1}$.

Niu et al. (2002) explored the effect of prevernalization DLI on the flowering of three species. They hypothesized that high DLI $\left(14 \mathrm{~mol} \cdot \mathrm{m}^{-2} \cdot \mathrm{d}^{-1}\right)$ before vernalization would improve plant flowering and survival following vernalization because of enhanced carbohydrate loading; however, the opposite response was observed. Columbine (Aquilegia $\times$ hybrida) and lavender plants had higher survival rates and improved flowering at a low DLI $\left(4 \mathrm{~mol} \cdot \mathrm{m}^{-2} \cdot \mathrm{d}^{-1}\right)$ treatment for 5 weeks before vernalization. This response may have been because of the light quality delivered by the high-pressure sodium lamps before vernalization, which may not have allowed the plants to properly harden before the vernalization period.

Lettuce. Metabolite concentrations of hydroponic lettuce measured on a fresh weight basis increased as DLI increased from 4 to 14 $\mathrm{mol} \cdot \mathrm{m}^{-2} \cdot \mathrm{d}^{-1}$ (Gent, 2014). The metabolites included amino acids, soluble sugars, and organic acids. Nitrates did not increase with DLI. Thus, the authors recommend to harvest lettuce for human consumption after a moderately high DLI has accumulated by the afternoon when all metabolites, other than nitrates, are at their highest. As DLI increased, the leaf area to shoot weight ratio decreased linearly and shoot dry weight increased linearly. Albright et al. (2000) identified $16-17 \mathrm{~mol} \cdot \mathrm{m}^{-2} \cdot \mathrm{d}^{-1}$ as optimal for hydroponic lettuce production. Lower DLI resulted in insufficient head size, and leaf tip burn occurred when the optimal DLI were 
exceeded. Leaf tip burn appears to be caused by a localized calcium deficiency that results when growth rates, due to high DLI, exceed the supply of calcium (Frantz et al., 2004).

Turfgrass. For turfgrass applications, DLI responses identify the shade tolerance of various species. Zhang et al. (2017) reported that bermudagrass (Cyndon dactylon $\times$ Cyndon transvaalensis) requires a minimum DLI of $9.2 \mathrm{~mol} \cdot \mathrm{m}^{-2} \cdot \mathrm{d}^{-1}$ during the winter to 21.4 $\mathrm{mol} \cdot \mathrm{m}^{-2} \cdot \mathrm{d}^{-1}$ during the summer, whereas zoysia (Zoysia $\mathrm{sp}$.) requires $5.9 \mathrm{~mol} \cdot \mathrm{m}^{-2} \cdot \mathrm{d}^{-1}$ during the winter and 10.9 during the summer. DLI is particularly important in putting greens because the leaves are mowed daily and a high DLI is required to continually regenerate new growth. Hodges (2016) reported that $27.1-42.3 \mathrm{~mol} \cdot \mathrm{m}^{-2} \cdot \mathrm{d}^{-1}$ was required during bermudagrass putting green establishment, whereas Bunnell et al. (2005) determined that bermudagrass putting greens required $32.6 \mathrm{~mol} \cdot \mathrm{m}^{-2} \cdot \mathrm{d}^{-1}$ to maintain acceptable turf quality. Thus, trees located near putting greens can cause shading problems that reduce turf quality.

Interactions. The interaction of DLI with other environmental parameters has been explored in several studies. The concept of photothermal ratio (PTR) was introduced by Liu and Heins (2002). This concept suggests that plant quality is directly related to the ratio of DLI to the average daily temperature. The unit for PTR is $\mathrm{mol} \cdot \mathrm{m}^{-2}$.degree- $\mathrm{d}^{-1}$. Plant quality refers to branching, stem diameter, flower size, and pigment development. Plant quality may increase as DLI increases relative to temperature. Thus, high DLI and low temperatures produce the highest quality plants. Conversely, low DLI and high temperatures produce the poorest plant quality. Blanchard et al. (2011b) observed that petunia quality was greater under a high vs. a low PTR. Their model illustrates how a petunia grown under high temperatures should be grown under a higher DLI to improve plant quality. Niu et al. (2001b) observed a linear increase in dry mass and flower bud number of campanula ( $C$. carpatica) as PTR increased from 0.2 to $1.0 \mathrm{~mol} \cdot \mathrm{m}^{-2} \cdot$ degree $-\mathrm{d}^{-1}$.

During summer months, shade curtains in greenhouses are used to manage temperatures by limiting the solar energy transmitted to the underlying crop. Shading reduces DLI which has obvious consequences for plant growth; however, heat stress can also have deleterious consequences. Warner and Erwin (2005) addressed this dilemma with their study on the effect of temperature and DLI on flowering of five herbaceous ornamental species. They found that reducing DLI with a shade curtain reduced plant growth and flowering at both 20 and $32{ }^{\circ} \mathrm{C}$. Therefore, shading proved to be detrimental to these species, regardless of the temperature provided. This suggests two options: 1) growers are better off investing in additional cooling systems rather than on using shade curtains as the primary means of climate control during the summer and 2) there are benefits to choosing shade curtains with higher transmissions percentages to avoid providing excessively low DLI under deployed shade curtains. The authors conclude that the worstcase scenario for plant growth and flowering is low DLI and high temperature, i.e., a low PTR, and shade curtains often create these conditions in commercial operations during summer months.

A couple of studies explored the relationship between DLI and irrigation and fertilization practices. Nemali and van Iersel (2004b) observed that the optimal fertilizer electrical conductivity for petunia and wax begonia did not change with DLI; thus, they concluded that fertilizations practices do not depend on DLI. Solar radiation has long been used to predict evapotranspiration in agronomic crops. More recently, van Iersel et al. (2010) used DLI along with plant age to predict daily water use of petunias. Their model predicted that each additional 1 $\mathrm{mol} \cdot \mathrm{m}^{-2} \cdot \mathrm{d}^{-1}$ resulted in a $1.14 \mathrm{~mL} \cdot \mathrm{d}^{-1}$ increase in water use.

Future research. After reviewing numerous publications exploring plant responses to DLI, we have several suggestions that researchers should consider to improve the usefulness of their experimentation: 1) Future DLI experiments should be designed, whenever possible, to deliver a sufficiently wide range of DLI treatments to provide broader response curves. Many studies report the maximum plant response to DLI to also be the maximum DLI treatment provided during the experiment, i.e., the optimal DLI was not identified because the response never reached a plateau or a supraoptimal DLI. 2) Final data collection for flowering responses should include a count of the nodes below the terminal flower or first axillary flower. These data help to interpret the effects of DLI on flowering and provide a better understanding of plant height responses. 3) Leaf temperatures should be measured under the different DLI treatments to differentiate between temperature and DLI responses. Plant temperatures typically increase as light intensity increases (Faust and Heins, 1998), which makes separating plant responses to temperature and DLI difficult when leaf temperatures are not reported. 4) Leaf area measurements recorded over time allow for the reporting of normalized DLI measurements which have tremendous potential for improving the interpretation of plant responses to DLI and for improving the recommended DLI for different size or aged plants. Normalized DLI measurements are particularly useful in sole-source lighting situations where LEDs deliver a fixed light intensity throughout the life of the crop. When young plants with a low leaf area index are placed in these environments, the DLI may be excessive; however, as the canopy grows, the plants can use higher DLIs. Thus, DLI recommendations can be adjusted over time based on the increasing leaf area.

\section{Literature Cited}

Albright, L.D., A.J. Both, and A.J. Chiu. 2000. Controlling greenhouse light to a consistent daily light integral. Trans. ASAE 43:421-431.
Armitage, A.M., W.H. Carlson, and J.A. Flore. 1981. The effect of temperature and quantum flux density on the morphology, physiology, and flowering of hybrid geraniums. J. Amer. Soc. Hort. Sci. 106:643-647.

Blanchard, M.G., E.S. Runkle, and J.M. Frantz. 2011a. Energy-efficient greenhouse production of Petunia and Tagetes by manipulation of temperature and photosynthetic daily light integral. Acta Hort. 893:857-864.

Blanchard, M.G., E.S. Runkle, and P.R. Fisher. 2011b. Modeling plant morphology and development of petunia in response to temperature and photosynthetic daily light integral. Scientia Hort. 129:313-320.

Blonquist, M. and B. Bugbee. 2017. Principles and approaches for measuring net radiation. In: J. Hatfield (ed.). Agroclimatology. Amer. Soc. Agron. Publ. Madison, WI.

Both, A.J. and J.E. Faust. 2017. Light transmission. In: Light management in controlled environments. R. Lopez and E. Runkle (eds.). Meister Media Worldwide, Willoughby, $\mathrm{OH}$.

Bunnell, B.T., L.B. McCarty, J.E. Faust, W.C. Bridges, and N.C. Rajapakse. 2005. Quantifying a daily light integral requirement of a 'TifEagle' bermudagrass golf green. Crop Sci. 45:549-574.

Chong, J.A. 2006. Modeling poinsettia stock plant canopies and their production of cuttings. Clemson Univ., Clemson, SC, PhD Diss.

Chong, J.A., U.C. Samarakoon, and J.E. Faust. 2014. Effects of daily light integral and canopy density on shoot growth and development in a poinsettia (Euphorbia pulcherrima Willd. ex. Klotsch) stock plant canopy. HortScience 49:51-54.

Christiaens, A., P. Lootens, I. Roldàn-Ruiz, E. Pauwels, B. Gobin, and M-C. Van Labeke. 2014. Determining the minimum daily light integral for forcing of azalea (Rhododendron simsii). Scientia Hort. 177:1-9.

Currey, C.J. and J.E. Erwin. 2011. Photosynthetic daily light integral impacts growth and flowering of several Kalanchoe species. HortTechnology 21:98-102.

Currey, C.J., V.A. Hutchinson, and R.G. Lopez. 2012. Growth, morphology, and quality of rooted cuttings of several herbaceous annual bedding plants are influenced by photosynthetic daily light integral during root development. HortScience 47:25-30.

Currey, C.J. and R.G. Lopez. 2015. Biomass accumulation and allocation, photosynthesis, and carbohydrate status of New Guinea impatiens, geranium, and petunia cuttings are affected by photosynthetic daily light integral during root development. J. Amer. Soc. Hort. Sci. 140:542-549.

Enfield, A., E. Runkle, R. Heins, and A. Cameron. 2003. Herbaceous perennials: Phlox paniculata. Greenhouse Grower 21(6):66-74.

Erwin, J.E. and R.M. Warner. 2002. Determination of photoperiodic response group and effect of supplemental irradiance on flowering of several bedding plant species. Acta Hort. 580:95-100.

Fausey, B.A., R.D. Heins, and A.C. Cameron. 2005. Daily light integral affects flowering and quality of greenhouse-grown Achillea, Gaura, and Lavandula. HortScience 40:114 118.

Faust, J.E. 2012. Light, p. 83-94. In: C. Beytes (ed.). Ball RedBook. 18th ed. Ball Publ., Chicago, IL.

Faust, J.E. and R.D. Heins. 1998. Modeling shoottip temperature in the greenhouse environment. J. Amer. Soc. Hort. Sci. 123:208-214. 
Faust, J.E., V.B. Holcombe, N.C. Rajapakse, and D.R. Layne. 2005. The effect of daily light integral on bedding plant growth and flowering. HortScience 40:645-649.

Frantz, J.M., G. Ritchie, N.N. Cometti, J. Robinson, and B. Bugbee. 2004. Exploring the limits of crop productivity: Beyond the limits of tipburn of lettuce. J. Amer. Soc. Hort. Sci. 129:331-338.

Garland, K.F., S.E. Burnett, M.E. Day, and M.W. van Iersel. 2012. Influence of substrate water content and daily light integral on photosynthesis, water use efficiency, and morphology of Heuchera americana. J. Amer. Soc. Hort. Sci. 137:57-67.

Garland, K.F., S.E. Burnett, L.B. Stack, and D. Zhang. 2010. Minimum daily light integral for growing high-quality coleus. HortTechnology 20:919-934.

Gent, M. 2014. Effect of daily light integral on composition of hydroponic lettuce. HortScience 49:173-179.

Hodges, B.P. 2016. Quantifying a daily light integral for establishment of warm-season cultivars on putting greens. Crop Sci. 56:2818-2826.

Hutchinson, V.A., C.J. Currey, and R.G. Lopez. 2012. Photosynthetic daily light integral during root development influences subsequent growth and development of several herbaceous annual bedding plants. HortScience 47:856-860.

Karlsson, M.G. 2002. Flower formation in Primula vulgaris is affected by temperature, photoperiod and daily light integral. Scientia Hort 95:99-110.

Kjaer, K.H. and C-O. Ottosen. 2011. Growth of chrysanthemum in response to supplemental light provided by irregular light breaks during the night. J. Amer. Soc. Hort. Sci. 136:3-9.

Kjaer, K.H., C-O. Ottosen, and B.N. Jørgensen. 2012. Timing growth and development of Campanula by daily light integral and supplemental light level in a cost-efficient light control system. Scientia Hort. 143:189-196.

Korczynski, P.C., J. Logan, and J.E. Faust. 2002. Mapping monthly distribution of daily light integrals across the contiguous United States. HortTechnology 12:12-16.

Liu, B. and R.D. Heins. 2002. Photothermal ratio affects plant quality in 'Freedom' Poinsettia. J. Amer. Soc. Hort. Sci. 127:20-26.

Loehrlein, M.M. and R. Craig. 2004. The effect of daily light integral on floral initiation of Pelargonium $\times$ domesticum LH Bailey. HortScience 39:529-532.

Lopez, R.G. 2007. Stock plant and propagation photosynthetic daily light integral and storage influences postharvest performance of herbaceous cuttings. Dept. Hort., Michigan State Univ., East Lansing, MI, PhD Diss.
Lopez, R.G. and E.S. Runkle. 2008. Photosynthetic daily light integral during propagation influences rooting and growth of cuttings and subsequent development of New Guinea impatiens and petunia. HortScience 43:2052-2059.

Marion, W. and S. Wilcox. 1994. Solar radiation data manual for flat-plate and concentrating collectors. Natl. Renewable Energy Lab, Golden, CO.

Moccaldi, L.A. and E.S. Runkle. 2007. Modeling the effects of temperature and photosynthetic daily light integral on growth and flowering of Salvia splendens and Tagetes patula. J. Amer. Soc. Hort. Sci. 132:283-288.

Nemali, K.S. and M.W. van Iersel. 2004a. Acclimation of wax begonia to light intensity: Changes in photosynthesis, respiration, and chlorophyll concentration. J. Amer. Soc. Hort. Sci. 129:745-751.

Nemali, K.S. and M.W. van Iersel. 2004b. Light intensity and fertilizer concentration: II. Optimal fertilizer solution concentration for species differing in light requirement and growth rate. HortScience 39:1293-1297.

Niu, G., R.D. Heins, A.C. Cameron, and W.H. Carlson. 2001a. Temperature and daily light integral influence plant quality and flower development of Campanula carpatica 'Blue Clips', 'Deep Blue Clips', and Campanula 'Birch Hybrid'. Scientia Hort. 36:664-668.

Niu, G., R.D. Heins, A.C. Cameron, and W.H Carlson. 2001b. Day and night temperatures, daily light integral, and $\mathrm{CO}_{2}$ enrichment affect growth and flower development of Campanula carpatica 'Blue Clips'. Scientia Hort. 87:93-105.

Niu, G., R.D. Heins, A.C. Cameron, and W.H. Carlson. 2002. Prevernalization daily light integral and vernalization temperature influences flowering of herbaceous perennials. HortScience 37:1028-1031.

Oh, W., I.H. Cheon, K.S. Kim, and E.S. Runkle. 2009. Photosynthetic daily light integral influences flowering time and crop characteristics of Cyclamen persicum. HortScience 44:341-344.

Oh, W., Y.H. Rhie, J.H. Park, E.S. Runkle, and K.S. Kim. 2008. Flowering of cyclamen is accelerated by an increase in temperature, photoperiod, and daily light integral. J. Hort. Sci. Biotechnol. 83:559-562.

Owen, W.G. and R.G. Lopez. 2018. Propagation daily light integral and root-zone temperature influence rooting of single-internode Pennisetum $\times$ advena culm cuttings. HortScience 53:176-182.

Perez, R., P. Ineichen, K. Moore, M. Kmiecik, C. Chain, R. George, and F. Vignola. 2002. A new operational model for satellite-derived irradi- ances: Description and validation. Sol. Energy 73:307-317.

Pramuk, L.A. and E.S. Runkle. 2005a. Photosynthetic daily light integral during the seedling stage influences subsequent growth and flowering of Celosia, Impatiens, Salvia, Tagetes, and Viola. HortScience 40:1336-1339.

Pramuk, L.A. and E.S. Runkle. 2005b. Modeling growth and development of Celosia and Impatiens in response to temperature and photosynthetic daily light integral. J. Amer. Soc. Hort. Sci. 130:813-818.

Renewable Resource Data Center. 2018. Solar resource information. Solar Resource Data. National Solar Radiation Database. 6 June 2018. <http://www.rredc.nrel.gov/solar/old_ data/nsdrb/>

Rohwer, C.L. and R.D. Heins. 2007. Daily light integral, prevernalization photoperiod, and vernalization temperature and duration control flowering of easter cactus. HortScience 42:1596-1604.

Thimijan, R.W. and R.D. Heins. 1983. Photometric, radiometric, and quantimetric light units of measure: A review of procedures for interconversion. HortScience 18:818-822.

Torres, A.P. and R.G. Lopez. 2010. Commercial greenhouse production: Measuring daily light integral in a greenhouse. Purdue Agr. Ext. HO238-W.

Torres, A.P. and R.G. Lopez. 2011. Photosynthetic daily light integral during propagation of Tecoma stans influences seedling rooting and growth. HortScience 46:282-286.

van Iersel, M.W., S. Dove, J-G. Kang, and S.E. Burnett. 2010. Growth and water use of petunia as affected by substrate water content and daily light integral. HortScience 45:277-282.

Warner, R.M. and J.E. Erwin. 2003. Effect of photoperiod and daily light integral on flowering of five Hibiscus sp. Scientia Hort. 97:341351 .

Warner, R.M. and J.E. Erwin. 2005. Prolonged high temperature exposure and daily light integral impact growth and flowering of five herbaceous ornamental species. J. Amer. Soc. Hort. Sci. 130:319-325.

Wilcox, S. 2010. National solar radiation database 1991-2010 update: User's manual. National Renewable Energy Laboratory, Golden, CO.

Zhang, J., B. Glenn, J.B. Unruh, J. Kruse, K. Kenworthy, J. Erickson, D. Rowland, and L. Trenholm. 2017. Comparative performance and daily light integral requirements of warmseason turfgrasses in different seasons. Crop Sci. 57:2273-2282. 